\title{
Novas formas de visibilidade: representações de gênero e raça no audiovisual em Goiás ${ }^{1}$
}

New forms of visibility: audiovisual gender and race representations in Goiás

Nuevas formas de visibilidad: representaciones de género y raza en el audiovisual en Goiás

DOI: https://doi.org/10.1590/1809-5844202117

\section{Ceiça Ferreira ${ }^{1}$}

http://orcid.org/0000-0003-0625-6923

\section{Clarissa Carvalho ${ }^{1}$}

https://orcid.org/0000-0001-8128-097X

${ }^{1}$ (Universidade Estadual de Goiás, Curso de Cinema e Audiovisual. Goiânia - GO, Brasil).

\section{Resumo}

Embora no cinema brasileiro ainda predomine um ponto de vista branco e masculino, da produção de curtas-metragens em contextos regionais tem surgido diferentes vozes e perspectivas. Exemplo disso é a atuação de três jovens cineastas negros em Goiás: Vanessa Goveia, Tothi Cardoso e Raphael Gustavo da Silva e seus respectivos curtas (Viúva Negra, A Câmera de João e A Piscina de Caíque), a partir dos quais investigamos a intersecção de gênero e raça no audiovisual goiano. Com base no contexto de produção e na metodologia de análise fílmica, identificamos novas formas de visibilidade negra nas telas e atrás das câmeras.

Palavras-chave: Cineastas negros. Audiovisual goiano. Visibilidade. Representação. Gênero e raça.

\begin{abstract}
Although a white and male point of view still predominates in Brazilian cinema, the production of short films in regional contexts has given rise to different voices and perspectives. An example of this is the performance of three young black filmmakers in Goiás: Vanessa Goveia, Tothi Cardoso and Raphael Gustavo da Silva and their respective short films (Viúva Negra, A Câmera de João and A Piscina de Caíque), from which we investigated the intersection of gender and race in the audiovisual sector in the state of Goiás. Based on the production context and the methodology of film analysis, we identified new forms of black visibility on the screens and behind the cameras.
\end{abstract}

1 Este artigo traz os resultados da pesquisa de iniciação científica (PIBIC/UEG) "Por novas formas de visibilidade: gênero e raça na cinematografia goiana", realizada de agosto de 2017 a julho de 2018, no projeto de pesquisa "A branquitude como ideal estético audiovisual”. Discussões iniciais foram apresentadas no III SEJA - Gênero e Sexualidade no Audiovisual, realizado de 22 a 24 de novembro de 2017 em Goiânia (GO), no trabalho "A mostra Filmes de Preto e o protagonismo negro no audiovisual goiano". 
Keywords: Young black filmmakers. Audiovisual in the state of Goiás. Visibility. Representation. Gender and race.

\section{Resumen}

Aunque todavía hay un punto de vista blanco y masculino en el cine brasileño, la producción de cortometrajes en contextos regionales ha dado lugar a diferentes voces y perspectivas. Un ejemplo de esto es el desempeño de tres jóvenes cineastas negros en Goiás: Vanessa Goveia, Tothi Cardoso y Raphael Gustavo da Silva y sus respectivos cortometrajes (Viúva Negra, A Câmera de João y A Piscina de Caíque), desde los cuales investigamos la intersección de género y raza en el sector audiovisual en Goiás. Teniendo en cuenta el contexto de la producción y la metodología del análisis de películas, identificamos nuevas formas de visibilidad del negro en las pantallas y detrás de las cámaras.

Palabras clave: Cineastas negros. Audiovisual en el estado de Goiás. Visibilidad. Representación. Género y raza.

\section{Introdução}

Buscando investigar a diversidade no cinema brasileiro, tanto nas telas, quanto nos bastidores, é que o Grupo de Estudos Multidisciplinares da Ação Afirmativa (GEMAA) do IESP-UERJ realizou uma análise quantitativa dos filmes nacionais de maior bilheteria entre 2002 e 2012, que somam 218 longas-metragens de ficção, 226 diretores, 412 roteiristas e 939 atrizes e atores. Tal estudo constatou a ínfima participação negra, pois somente 14\% de atores e $4 \%$ de atrizes (pretos/as e pardos/as) estão no total dos elencos principais, à medida que atrizes e atores brancos são respectivamente 36\% e 44\%; no âmbito da produção, tem-se a predominância de indivíduos brancos do gênero masculino na roteirização e direção dos filmes (respectivamente $84 \%$ e 68\%), enquanto as mulheres brancas correspondem somente a $13 \%$ e $24 \%$ de profissionais nessas funções; e homens negros são apenas $2 \%$ dos diretores e 4\% dos roteiristas (CANDIDO; MORATELLI; DAFLON; FERES JÚNIOR, 2014, CANDIDO; TOSTE, 2014). A assimetria racial acentua-se ainda mais quando se articula ao fator gênero, ressaltam tais autores, ao verificarem que, no período estudado, nenhum filme foi dirigido ou roteirizado por uma mulher negra. Isso confirma ainda que os padrões de exclusão presentes na televisão (ARAÚJO, 2008, CAMPOS; FERES JÚNIOR, 2015) persistem no cinema brasileiro comercial e confirmam raça como uma forma de classificação social, que hierarquiza os níveis de aceitação e o reconhecimento dos indivíduos a partir do fenótipo, conforme indica Guimarães (2011).

Esse panorama de disparidades também foi constatado em um estudo da Agência Nacional do Cinema (ANCINE), publicado em janeiro de 2018, que considerou os 142 longas-metragens lançados comercialmente em salas brasileiras de exibição no ano de 2016. Deste total, 75,4\% foram dirigidos por homens brancos, $19,7 \%$ por mulheres brancas e $2,1 \%$ por homens negros - e novamente, nenhuma mulher negra atuou nas funções de roteirista ou diretora (BRASIL, 2018). Tais dados indicam a necessidade de ter negros e negras nas 
diversas funções de produção cinematográfica (direção, roteiro, fotografia, entre outros) para se questionar o monopólio de quem constrói as representações audiovisuais e também como possibilidade para mudar a forma como as narrativas e as personagens negras são predominantemente concebidas. "Quando o roteirista de um filme é negro, aumenta em $52,5 \%$ a chance de haver mais um ator ou atriz negros no elenco. Quando se trata do diretor, esse número chega a 65,8\%” (BRASIL, 2018, p. 19).

Nesse sentido, vale destacar o movimento Dogma Feijoada, criado no ano 2000 (durante o Festival Internacional de Curtas-Metragens de São Paulo) pelos cineastas Noel Carvalho, Jeferson De, Joel Zito Araújo, Lilian Solá Santiago, Luiz Antonio Pillar, assim como atores, atrizes e outros/as profissionais negros e negras, que apresentava reivindicações de inserção no mercado audiovisual como um exercício político de assumir a construção de tais narrativas e reverter visões limitadas. Dessa forma, ter um diretor e um protagonista negro, a temática do filme estar relacionada à cultura negra-brasileira, assim como proibir personagens estereotipados e evitar super-heróis ou bandidos, e destacar o negro comum brasileiro são alguns dos mandamentos desse manifesto intitulado Gênese do Cinema Negro Brasileiro (CARVALHO, 2005).

Também buscando assumir o protagonismo nessa área, é que mulheres negras de várias regiões do país têm ganhado destaque no cinema de curta-metragem, com a participação em festivais e mostras nacionais e internacionais. Em contraponto à intersecção de gênero e raça que opera processos de exclusão no contexto social e também na produção cinematográfica nacional, conforme já mencionado, essas jovens diretoras inspiram-se na atuação pioneira de Adélia Sampaio (primeira cineasta negra brasileira, que iniciou sua carreira nos anos de 1970 e continua realizando filmes) para arquitetar uma produção audiovisual caracterizada pela diversidade de formatos, práticas e formas de representação (FERREIRA; SOUZA, 2017).

Dessa forma, apesar do cenário pouco diverso na produção de longas, ainda centralizado no eixo Rio-São Paulo, tem-se desenvolvido nas últimas décadas, especialmente no cinema de curta-metragem, outras iniciativas dentro das produções locais de cada Estado. Um exemplo disso é a mostra Filmes de Preto, realizada em Goiânia para o lançamento dos curtas Viúva Negra, A Câmera de João e A Piscina de Caíque, dirigidos respectivamente por Vanessa Goveia, Tothi Cardoso e Raphael Gustavo da Silva. A partir de tal mostra e dessas três produções de jovens diretores/as negros/as, é que este propõe discutir a produção audiovisual em Goiás e, principalmente, analisar as representações de gênero e raça, buscando identificar continuidades e possíveis inovações nas formas de visibilidade para a população negra.

\section{A mostra Filmes de Preto e o audiovisual goiano}

Em consonância com tais discussões em pauta no contexto nacional, Raphael Gustavo da Silva, Vanessa Goveia e Tothi Cardoso organizaram a mostra Filmes de Preto (Figura 1) para o lançamento de seus curtas, respectivamente Viúva Negra, A Câmera de João e A Piscina de Caíque. Tal evento foi realizado no dia 7 de maio de 2017, no Cine Cultura, em 
Goiânia e agrega o desejo desses três jovens cineastas de pensar o protagonismo negro na produção audiovisual goiana.

Figura 1 - Material de Divulgação online da mostra e foto dos realizadores com cartazes dos filmes

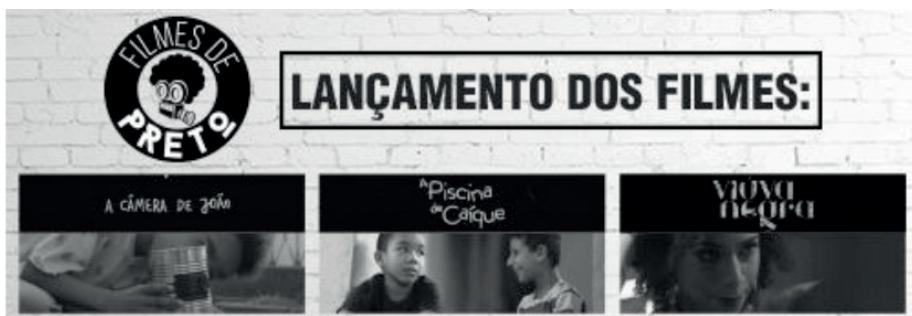

\section{DE MAIO DE 2017}

17 HORAS - CINE CULTURA - PRAÇA CIIVICA - CENTRO DE GOIÂNIA ENTRADAFRANCA

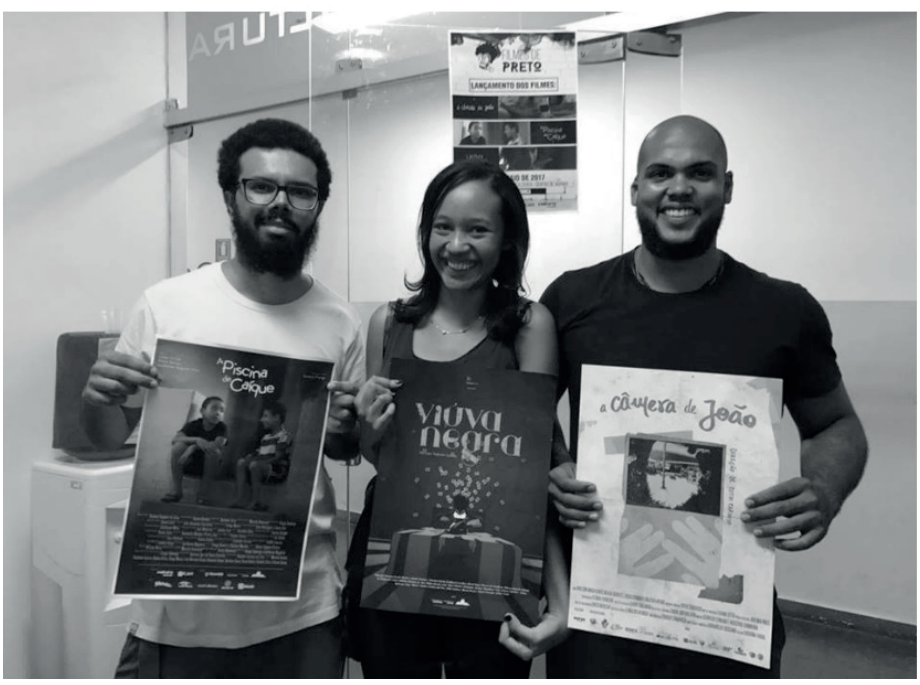

Fonte: Evento FILMES de PRETO e Página do filme Viúva Negra do Facebook (Foto: Ricardo Alvez)².

Essa primeira exibição de filmes foi concebida pelos três como um movimento nascido dentro do circuito de produções cinematográficas goianas, no qual se propõem a falar sobre como as hierarquias existentes dentro dos sets influenciam a construção das personagens negras. Em entrevista ao jornal $O$ Popular, Vanessa destaca:

"Quase sempre é visível que, durante um set de filmagens, os negros ocupam cargos braçais ou inferiores. Lutamos pela visibilidade”, pontua Vanessa

2 Imagem disponível em: www.facebook.com/viuvanegrafilme/photos/a.625351327612915/802853393196040. Acesso em: 2 abr. 2019. 
Gouveia, diretora do curta-metragem Viúva Negra, da Estratosfilmes com patrocínio da Secretaria do Audiovisual. Segundo a cineasta, é preciso estar atento e forte contra o preconceito, mesmo nas áreas culturais, como no cinema. "No meu caso em específico, por exemplo, ainda tenho que me sobrepor ao fato de ser uma mulher, jovem de 23 anos, e me colocar como uma realizadora audiovisual”, reitera. (FERREIRA, 2017b, s/p) ${ }^{3}$.

Pensando os âmbitos da produção e da representação, vale ressaltar que os curtas Viúva Negra, de Vanessa Goveia e A Piscina de Caíque, de Raphael Gustavo da Silva foram contemplados no edital "Curta Afirmativo 2014: Protagonismo de Cineastas AfroBrasileiros na Produção Audiovisual Nacional”, que selecionou 21 propostas de curtasmetragens de vários estados brasileiros. Essa foi a segunda edição desse edital criado em 2012 pela Secretaria do Audiovisual do Ministério da Cultura em parceria Secretaria de Políticas de Promoção da Igualdade Racial da Presidência da República (SEPPIR), com o objetivo de apoiar a produção de obras nacionais inéditas dirigidas por jovens negros/as, ao oferecer premiação de até R \$ 80 mil para a produção de 21 curtas metragens contemplados, que poderiam ser de temática livre, ficção ou documentário (CURTA..., 2015).

Após essas duas edições, o edital Curta Afirmativo foi descontinuado, assim como o prêmio Carmen Santos de Cinema de Mulheres. Apesar do término dessas duas importantes ações afirmativas, as pesquisas desenvolvidas pela Ancine sobre gênero e raça orientaram a aprovação em 2018, de cotas para mulheres, negros e indígenas no edital de produção de longas-metragens (APROVADAS..., 2018). Entretanto, o início do governo do Presidente Jair Bolsonaro em 2019 criou um contexto desfavorável para o audiovisual e para as ações afirmativas, visto a extinção do Ministério da Cultura (que passou a ser uma Secretaria vinculada ao Ministério da Cidadania), a perspectiva de cortes significativos nos investimentos futuros para o setor, o risco de censura e um período de paralisação de verbas da Ancine (entre abril e maio) gerou instabilidade que ainda perdura em 2020 entre os profissionais da área (RISTOW, 2019).

Apesar dessa atual conjuntura nacional, vale mencionar as transformações que têm ocorrido na produção audiovisual em Goiás nos últimos anos. A criação em 1999, do Festival Internacional de Cinema e Vídeo Ambiental (FICA), realizado até 20184, com duas categorias de prêmio para filmes do Estado; a mostra da Associação Brasileira dos Documentarista (ABD-Seção Goiás), criada em 2003 dentro da programação do FICA; e o Festival Goiânia Mostra Curtas, que em 2019 chegou à sua 19a edição, as quais foram por muito tempo as principais janelas de exibição das produções goianas ${ }^{5}$ (SILVA, 2019, LEÃO, 1999). Entretanto, é com a formação profissional que essa produção local passa a ganhar

3 Rei Souza, cineasta negro da cidade de Anápolis também integra o movimento Filme de Preto e também entrevistado nessa reportagem, ressalta esse desejo por visibilidade como aspecto fundamental de sua produção (FERREIRA, 2017b).

4 Em virtude dos cortes nos recursos para a cultura no Estado, em 2019 não foi realizada a XXI edição do festival.

5 Vale mencionar ainda dois festivais: o Festcine Goiânia, criado em 2004 pela Prefeitura da cidade e que em setembro de 2019 realizou sua $9^{a}$ Edição, com a exibição de 22 filmes (dez longas e 12 curtas), no Cine Goiânia Ouro; e o Festival de Documentários 
mais força e reconhecimento. A Universidade Estadual de Goiás (UEG) criou, em 2006, o curso de Comunicação Social, com habilitação em Audiovisual, que em 2014 passou a se chamar Cinema e Audiovisual. Deste curso, os três jovens cineastas que aqui destacamos são egressos (Vanessa e Tothi, da graduação; e Raphael, da pós-graduação em Cinema e Audiovisual: Linguagens e Processos de Realização, criada em 2016). A esse trio, juntam-se Thais Oliveira (uma das primeiras profissionais da área de som no Estado e hoje professora do curso), Ludielma Laurentino, Benedito Ferreira, Getúlio Ribeiro, Larissa Fernandes e Jarleo Barbosa, entre outros/as profissionais que compartilham a mesma formação e em alguns casos, também, a criação de suas próprias produtoras. Em 2015, foi criado, na cidade de Goiás, o curso de bacharelado em Cinema e Audiovisual do Instituto Federal de Goiás (IFG) e um curso Técnico Integrado ao Ensino Médio em Produção de Áudio e Vídeo, com duração de três anos (PRADO, 2019).

Essa recente formação superior em Goiás e nos estados de Mato Grosso e Mato Grosso do Sul, nos quais respectivamente os cursos entraram em funcionamento em 2018 (na UFMT) e em 2019 (na UFMS) (AULA..., 2018, TONHATI, 2018), bem como a existência de apenas um bacharelado em Cinema e Audiovisual na Região Norte, criado em 2010 na Universidade Federal do Pará (UFPA) ${ }^{6}$, nos possibilita pensar a exclusão regional ainda existente no país. Pois, conforme aponta Ramos (2010), na universidade pública, os primeiros cursos de cinema foram criados ainda nos anos de 1960, primeiramente na Universidade de Brasília (UnB) ${ }^{7}$, depois na Universidade de São Paulo (USP) e na Universidade Federal Fluminense (UFF). Além disso, segundo levantamento de 2012, a Região Sudeste apresenta um total de dezesseis cursos de bacharelado em Cinema e Audiovisual, sendo nove apenas no estado de São Paulo (SILVA, 2012).

Voltando ao contexto local, a produção de filmes em curta-metragem ainda predomina em Goiás e se sustenta, principalmente, por meio de dois mecanismos de financiamento: a Lei Goyazes (Lei Estadual de Incentivo à Cultura, $n{ }^{\circ} 13.613$, de 2000 e regulamentada em 2001) e a Lei Municipal de Incentivo à Cultura (Lei no 8.666 de 21/06/1993, da Prefeitura de Goiânia), que funcionam por meio de renúncia fiscal (PRADO, 2019, GOIÁS..., 2017). Entretanto, o início de 2019 foi marcado pelo lançamento de seis longas: Alaska, de Pedro Novaes; Dias Vazios, de Robney Bruno Almeida; Hélio Nunes: Do módulo lunar ao fotojornalismo, de Ranulfo Borges; Hotel Mundial, de Jarleo Barbosa; Parque Oeste, de Fabiana Assis e Vermelha, de Getúlio Ribeiro ${ }^{8}$. Trata-se de um momento de efervescência do

Brasileiros - PirenópolisDoc, realizado pela Violeta Filmes, de 2015 e 2018. Porém, sua quinta edição não pode ser realizada, visto a suspensão em maio de 2019 dos editais do Fundo de Cultura e Arte do Estado.

6 Segundo informações do Blog do Curso de Cinema e Audiovisual da UFPA. Disponível em: http://cinemaufpa.blogspot.com/p/ apresentacao_23.html. Acesso em: 19 ago. 2020.

7 A criação do curso de cinema da UnB reuniu nomes importantes como Nelson Pereira dos Santos, Paulo Emílio Sales Gomes, Jean Claude Bernardet e Dib Luft, que também atuaram como docentes. Mas essa experiência foi interrompida pelo Regime Militar (SILVA, 2012). Atualmente, na Faculdade de Comunicação (FAC), são oferecidos os seguintes cursos: Audiovisual, Jornalismo, Comunicação Organizacional e Publicidade e Propaganda.

8 Parque Oeste e Vermelha ganharam as maiores premiações da $22^{\mathrm{a}}$ Mostra de Cinema de Tiradentes. O primeiro recebeu o levou o Troféu Carlos Reichenbach, dado pelo Júri Jovem ao melhor título da Mostra Olhos Livres; e o segundo foi escolhido como melhor da Mostra Aurora pelo Júri da Crítica e ganhador do Troféu Barroco. 
cinema em Goiás, especialmente pela atuação de jovens realizadores/as (NOLETO, 2019, O RENASCIMENTO, 2016, FERREIRA, 2017a).

De acordo com a GoFilmes (Associação de Produtoras de Cine \& TV em Goiás), em 2018 havia 28 longas-metragens e 26 séries de TV em produção no Estado, o que confirma Goiás como um dos polos mais importantes de produção de cinema e TV do Brasil ${ }^{9}$. Essa expansão do setor pode estar relacionada à criação do Fundo de Arte e Cultura de Goiás, lançado em 2013, e que se configura como “[...] a principal ação de dinamização artística do estado, com um volume que chegou a 33 milhões de reais em 2017, dos quais o audiovisual possui verba destacada por ser uma atividade mais cara e que emprega artistas e técnicos de diferentes áreas”, salienta Prado (2019, p. 252). Desse modo, observando esse contexto regional e suas articulações com o nacional, é que propomos a análise dos curtas Viúva Negra, A Câmera de João e A Piscina de Caíque, a partir dos referenciais teóricos e metodológicos que apresentamos a seguir.

\section{Analisar filmes, questionar representações}

Atentando-se para a relevância das práticas de representação na produção e circulação de sentidos, e principalmente para a construção das identidades, a pesquisadora Gomes (2003, p. 43) ressalta que "construir uma identidade negra positiva em uma sociedade que, historicamente, ensina ao negro, desde muito cedo, que para ser aceito é preciso negar-se a si mesmo, é um desafio enfrentado pelos negros e pelas negras brasileiros(as)”. Nesse sentido, Araújo (2008) enfatiza a branquitude como ideal estético na televisão e no cinema brasileiros, que se expressa na limitada participação negra e na naturalização desses profissionais em papéis subalternos ou estereotipados, como escravos e serviçais, sem densidade psicológica, limitados a espaços inferiorizados, enquanto personagens brancos tem as rédeas da ação, do olhar e do desejo; e fora das telas são considerados modelos de beleza e sucesso.

Hall (2016) destaca os estereótipos como prática significante integrada à manutenção da ordem social e simbólica, que se caracteriza por reduzir, naturalizar e fixar a diferença física; por implantar uma estratégia de exclusão simbólica de tudo que não se enquadra nos limites estabelecidos; e opera onde há desigualdade de poder. Considerando tais aspectos, é que a produção cinematográfica não pode ser desvinculada da esfera da interlocução social, visto seu papel central na difusão de assimetrias sociais, raciais e de gênero que caracterizam a convivência inter-racial brasileira, historicamente ancorada na valorização da mestiçagem e de um modelo estético branco.

As representações impostas à população negra e, principalmente, o monopólio de quem detém o poder de cria-las tem sido pauta constante de várias discussões e manifestações como, por exemplo, no início de 2020 as críticas da comunidade negra, em especial de profissionais do cinema, à escolha de um homem branco (o cineasta José Padilha) e uma mulher branca

9 Dados divulgados no vídeo institucional da Associação, veiculado no dia 27 de junho de 2019 em sua página no Facebook. Disponível em: https://www.facebook.com/associacaogofilmes/videos/2494824637269439/. Acesso em: 1 jul. 2019. 
(a roteirista Antonia Pellegrino) para as funções de direção e roteiro de uma série da Globo Play sobre a vereadora e ativista negra Marielle Franco, assassinada em 2018 (CASTRO, 2020) ${ }^{10}$; e a campanha "Eu poderia estar na novela O Segundo Sol" lançada no Facebook pela página Trick Tudo, no ano de 2018. Como forma de protesto à ausência de negros e negras em tal produção da Rede Globo, ambientada em Salvador/BA, a página indicou vários atores e atrizes negras que poderiam integrar o elenco dessa novela (AUSÊNCIA..., 2018). No entanto, vale pontuar também que, nos últimos anos, ainda de maneira tímida, tem emergido representações mais diversas na publicidade e em narrativas midiáticas no geral (como a cena de uma novela), “[...] que apresentam a presença positiva de indivíduos negros como protagonistas, bem como a representação de família em seus roteiros”, ressaltam Batista e Leite (2017, p. 24). Por isso, são consideradas contraintuitivas, ou seja, capazes de desafiar visões pré-estabelecidas no senso comum, atualizar ou mesmo deslocar os sentidos de estereótipos tradicionais e empreender a construção de contranarrativas e, assim, se configuram comom "[...] uma "outra/nova" proposta de visibilidade, do campo publicitário, às minorias sociais” (LEITE, 2011, p. 231).

Tais aspectos confirmam a pertinência de desenvolver uma análise fílmica de três curtas dirigidos por jovens realizadores/as negros. Para isso, utilizamos as contribuições de Vanoye e Goliot-Lété (1994) para a análise das relações de sentido construídas pelos elementos da linguagem cinematográfica (como enquadramentos, personagens, disposição no espaço fílmico, iluminação e trilha sonora, entre outros); e também os subsídios teóricometodológicos indicados por Stam e Shohat (2006) para o estudo dos discursos e hierarquias veiculadas pelas ficções cinematográficas.

O cinema traduz correlações de poder social em registros de primeiro plano e plano de fundo, de dentro da tela e fora da tela, silêncio e discurso. Para falar da "imagem" de um grupo social, precisamos fazer perguntas precisas a respeito das imagens e sons: Quanto espaço os diversos personagens ocupam na tomada? Quais personagens são ativos e dinâmicos, e quais personagens não passam de apoios decorativos? A linha de visão faz com que nos identifiquemos com um olhar, ao invés de outro? Os olhares de quem são correspondidos? Quais são ignorados? Como a linguagem corporal, a postura e a expressão facial comunicam atitudes arraigadas em hierarquias sociais, atitudes de arrogância, servilismo, ressentimento, orgulho? A música de quem dita a resposta emocional? Quais homologias dão forma à representação artística e étnico-política? (SHOHAT; STAM, 2006, p. 303).

10 Diante das críticas à escolha de tais profissionais e também às declarações racistas feitas pela roteirista Antonia Pellegrino na tentativa de justificar a escolha de José Padilha para a direção da série, a Rede Globo e a produtora Antifa Filmes decidiram escalar diretores e roteiristas negros para tal produção. 
Sob uma perspectiva que reconhece as dinâmicas interativas entre gênero e raça (e outros marcadores sociais) como eixos de poder distintos que estruturam a exclusão da população negra nas representações e incidem sobre os processos de reconhecimento social (GONZALEZ, 1984, CRENSHAW, 2002), tal exercício analítico centra-se na investigação de fragmentos de cada filme, buscando observar como gênero e raça se manifestam na construção da narrativa, na caracterização dos personagens e no âmbito de produção. A partir de tais elementos, procuramos identificar ambiguidades, fluxos, rupturas e continuidades com relação à cinematografia nacional e ao nosso imaginário cultural/social, ainda profundamente marcados pela experiência colonial, escravista e patriarcal.

\section{A fotografia, o olhar e A Câmera de João}

O curta A Câmera de João11, que tem direção e roteiro de Tothi Cardoso, é uma ficção ambientada no bairro de Campinas, em Goiânia, e aborda a relação do protagonista João (Lucas Romão) com seus avós Zeca e Sônia (interpretados por Adilson Magalhães ${ }^{12}$ e Neuza Borges ${ }^{13}$ ), em especial com o avô, fotógrafo que coleciona registros da cidade. Ao compartilhar suas fotos antigas e suas memórias afetivas do bairro, Vô Zeca ensina o neto a construir sua própria câmera e fazer suas próprias fotos.

O filme começa com imagens que percorrem ruas da cidade, compõem um enquadramento menor, parecem envelhecidas e são acompanhadas de uma música que parece indicar uma viagem ao passado. Depois, vemos que se trata do ponto de vista de João, que, concentrado, pela janela do carro, olha tudo pelo visor de sua câmera. Em off, destacase a voz de sua mãe informando que ele ficará na casa dos avós; ela recomenda-o a fazer as tarefas da escola, já que, em tom de reclamação, pontua "depois que seu avô te deu essa câmera, você não pensa em mais nada”. Essa fala da mãe vai soando baixinho, efetivamente distante daquele mundo mágico da fotografia, com o qual o menino está fascinado, como vemos por sua imagem refletida no retrovisor interno.

O garoto é deixado pela mãe na casa dos avós; ele chega correndo, recebe um beijo da avó e segue para o quarto de Vô Zeca, a quem entrega alguns materiais e mostra-se curioso para saber do que se trata, mas é hora de ir para a escola. Quando João retorna, já é hora do almoço, preparado pela avó, que carinhosamente o serve e novamente o menino fica na expectativa.

Em sequência posterior, João vai ao encontro do avô no cômodo dos fundos e a forma cuidadosa como o menino toca as coisas nos dá indícios das descobertas que virão. Vô Zeca pede para ele pegar uma caixa de madeira em cima de um armário velho e com o objeto em

11 Disponível no canal da produtora Dafuk Filmes: https://vimeo.com/202317652. Acesso em: 22 ago.2020.

12 Falecido em 2016, o ator mineiro Adilson Magalhães também conhecido por Adílson Maghá, atuou nas novelas Araguaia e Velho Chico, exibidas pela Rede Globo; e no cinema participou de vários filmes, como por exemplo Batismo de Sangue (Helvécio Ratton, 2007), Oração do Amor Selvagem (Chico Faganello, 2015) e Vazante (Daniela Thomas, 2017).

13 A atriz Neuza Borges é uma das atrizes negras pioneiras no cinema e na dramaturgia brasileira. Atuou em telenovelas brasileiras como Dancin' Days, A Indomada, O Clone e Salve Jorge; e dos filmes A deusa negra (Ola Balogun, 1978), Polaróides Urbanas (Miguel Falabella, 2008) e As Mães de Chico Xavier (Glauber Filho e Halder Gomes, 2011). 
mãos, temos um plano longo, que parece refletir a importância daquele momento, no qual o ancião tateia a caixa, abre-a e desata o laço que prende algumas fotografias. Enquanto isso, João permanece sentando no chão acompanhando essa espécie de reencontro do avô com o passado, pois trata-se de fotos antigas de Campinas, ou a "Velha Campininha das Flores", como Vô Zeca e vários moradores antigos ainda chamam esse bairro, um dos mais antigos do Estado de Goiás, onde se iniciou a construção do que viria a ser a capital Goiânia. Há nesse momento a escuta de uma paisagem sonora que remonta e evidencia a construção da memória afetiva desse lugar: o uso de sons como o de sinos da igreja e o de um alto-falante anunciando o jogo no Estádio Antônio Accioly. Mas essas fotos, agora mostradas em super close na mão de João, tem um significado ainda mais especial: foram as primeiras fotos que Vó Zeca fez, como ele relata, ao relembrar seu ofício de fotógrafo, exercido muitas vezes com a câmera emprestada de um amigo.

Entusiasmado com o trabalho do avô, no dia seguinte, João pega as fotos antigas e deixa de ir à aula para andar pelas ruas de Campinas. Com sua pequena polaroid, ele nos apresenta seu olhar sobre esses lugares (Figura 2), como a avenida 24 de Outubro, importante centro comercial; a praça do Coreto; a Igreja Matriz de Campinas; o estádio Antônio Accioly, do Atlético Clube Goianiense, um dos times mais tradicionais da capital; e o Palace Hotel, que agora é a Biblioteca Municipal Cora Coralina; a música indica essa jornada do garoto na descoberta do bairro e se junta ao barulho dos carros e das pessoas andando pelas ruas. Sobre os ruídos sonoros que aparecem com as imagens, segundo Caixeta e Oliveira (2015, p. 3) tais efeitos sonoros são conhecidos por meio do termo foley “[...] e seu objetivo é levar-nos a acreditar que somos parte de sua ação”. Articulando a composição sonora, as fotos antigas e os cliques do garoto, o filme apresenta passado e presente, relaciona as memórias afetivas do avô com a representação atual do espaço urbano e nos permitem uma maior aproximação com aquele lugar, com aquele cotidiano sob o olhar do menino fotógrafo.

Figura 2 - A fotografia, o passado e o presente
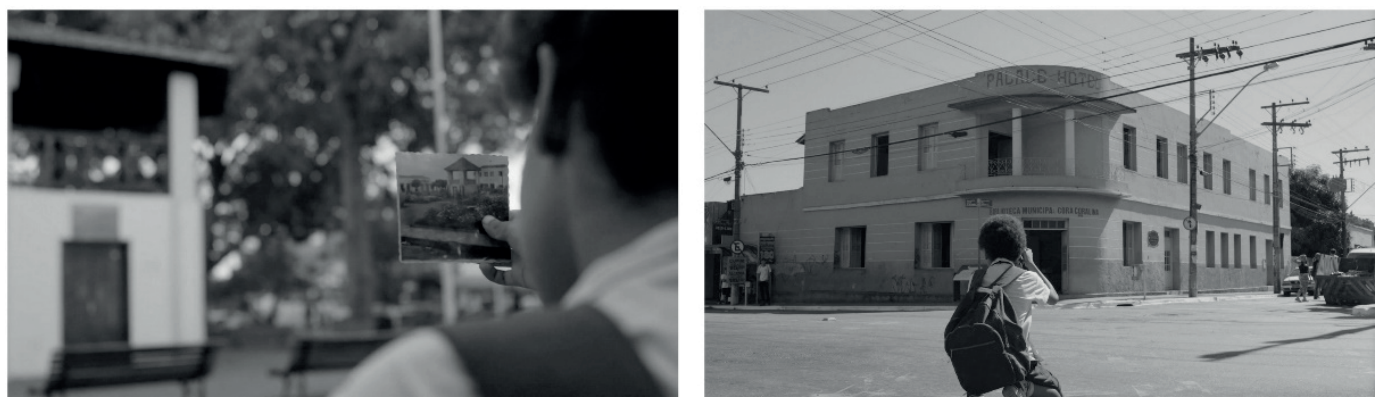

Fonte: Filme A Câmera de João (Tothi Cardoso, 2016).

Depois de um longo dia andando pelas ruas do bairro e por esses vários espaços, João volta para a casa e mesmo diante da preocupação dos avós com sua demora, ele fala de sua experiência, comparando como era o bairro no passado, quando seu avô o fotografou e 
as mudanças que ocorreram nesse intervalo de tempo, mostrando as fotos que fez durante o passeio. Atentamente, os avós ouvem e observam com encantamento o registro feito pelo neto (Figura 3).

Figura 3 - João mostrando suas fotografias para os avós
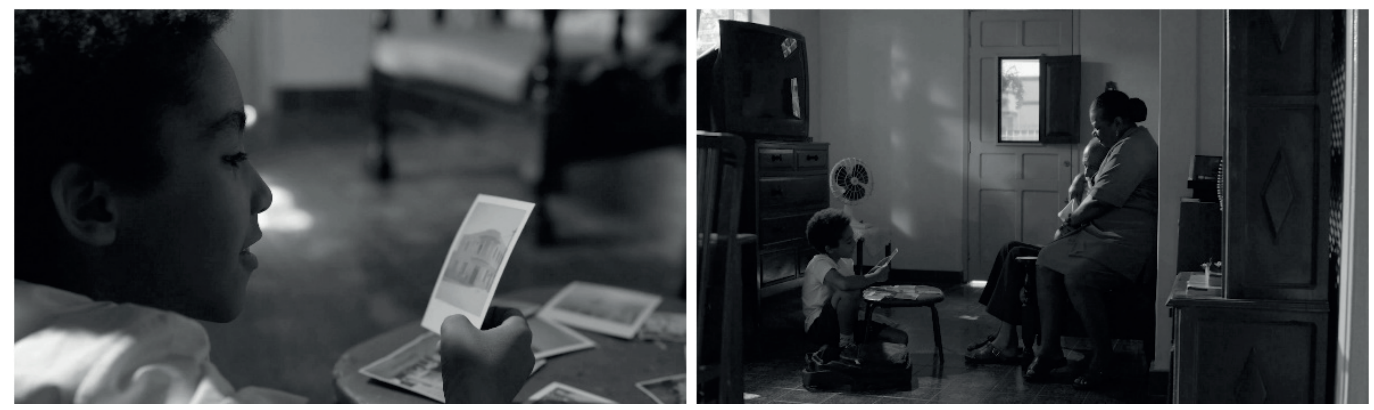

Fonte: Filme A Câmera de João (Tothi Cardoso, 2016).

Diante do interesse de João pela fotografia, Vô Zeca finalmente resolve usar os materiais que no início do filme o neto lhe entregara. Ele fala novamente de seu passado, lembrando que, quando não conseguia uma câmera emprestado, usava uma câmera de lata e, assim, ensina o pequeno fotógrafo a construir sua própria câmera de lata, uma pinhole ${ }^{14}$. Nas cenas seguintes, ele orienta todo o processo de criar o objeto e aliada às imagens, a música acentua a criatividade desse fazer executado por mãos infantis.

Depois de pronta, Vô Zeca pega a câmera e com suas próprias mãos, ensina o neto a fotografar. Em seguida, João tira foto da avó regando as plantas e de volta ao cômodo dos fundos que agora serve como laboratório fotográfico, segue novamente as orientações do avô para fazer o processo de revelação. Nas cenas seguintes, que constituem a sequência final do curta, João entrega a foto para o avô Zeca, que a sente com os dedos e, emocionado, expressa seu contentamento afagando carinhosamente o rosto do neto (Figura 4). Essa cena revela a potência da fotografia, como luz que cria imagem na câmera de lata e principalmente, como memória afetiva que possibilita ao avô, mesmo sem enxergar, transmitir ao pequeno João, o olhar e o fazer fotográfico.

14 Também conhecida como câmera escura, a câmera pinhole é uma máquina fotográfica que utiliza uma caixa totalmente fechada, onde por um pequeno orifício em um dos lados, a luz é captada e a imagem é projetada de forma invertida no pedaço de filme ou papel fotográfico do lado oposto. 
Figura 4 - Vô Zeca, João e fotografia

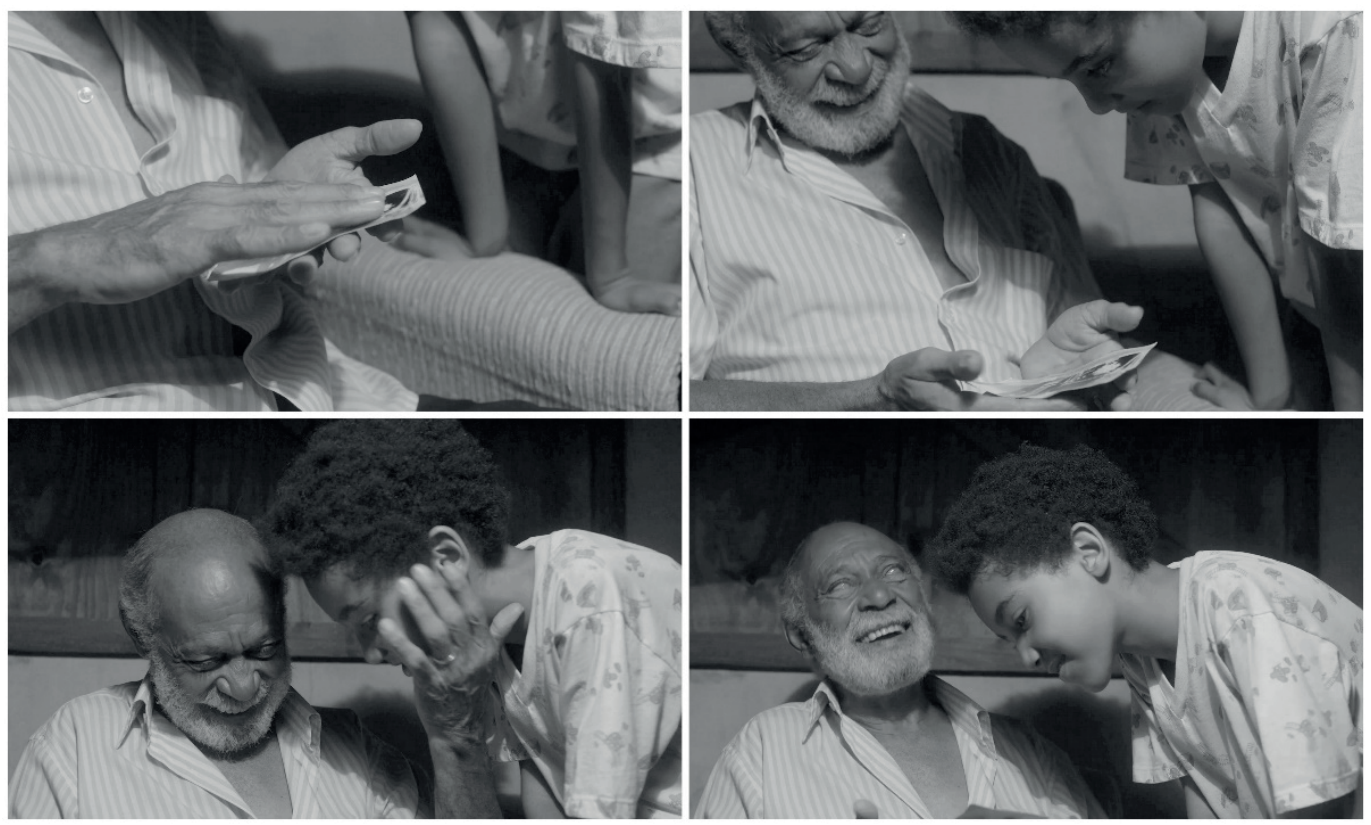

Fonte: Filme A Câmera de João (Tothi Cardoso, 2016).

Por meio da paixão pela fotografia, que une avô e neto, esse curta de Tothi Cardoso explora na narrativa audiovisual algo muito pertinente à população negra, que é o lugar de sujeito na história da fotografia, na qual ainda prevalece um imaginário branco e escravista, pois assim como o cinema, é também atravessada pelas assimetrias raciais, mesmo em sua dimensão técnica, já que o corpo feminino branco foi usado pela Kodac nos anos de 1940 para padronizar os tons de pele das impressões fotográficas (VELASCO, 2016).

Outro aspecto importante é como filme se propõe a problematizar esse poder da fotografia. Na técnica pinhole, “[...] há um esfacelamento total da busca pela objetividade fotográfica, o imprevisível é o mais importante. O resultado sempre será uma surpresa e é aí que reside uma das maiores potências da pinhole: o acaso”, conforme destaca Migliavacca (2009, p. 57). Dessa forma, Avô Zeca possibilita ao pequeno João não apenas criar sua própria câmera, mas também de subverter a busca pela representação da fotografia tradicional, estimulando o garoto a ter uma outra interpretação do fazer fotográfico, um outro olhar para a realidade.

\section{A Piscina de Caíque e o exercício do brincar}

Também explorando o universo infantil, o curta A Piscina de Caíque ${ }^{15}$, dirigido por Raphael Gustavo da Silva (que também exerce as funções de roteirista, diretor e produtor

15 Disponível no canal do Nosso Vera Jornal em: https://www.youtube.com/watch?v=K83LMpjPENk. Acesso em 19 ago. 2020. 
executivo), foi filmado no Conjunto Vera Cruz, na periferia de Goiânia e realizado em colaboração com os moradores do bairro. A ficção narra a história de Caíque (Lucas Orsida), que após sua mãe (Eliana Santos) ir para o trabalho, prepara junto com um amigo a área externa da casa para uma refrescante brincadeira: jogar água um no outro e escorregar no piso molhado e ensaboado (Figura 5). Também fazendo alusão a sons de brinquedos, a música realça esse momento lúdico e divertido dos dois garotos, que são observados com carinho pelo avô (Antonio Pitanga ${ }^{16}$ ).

Figura 5 - Brincadeira de escorregar
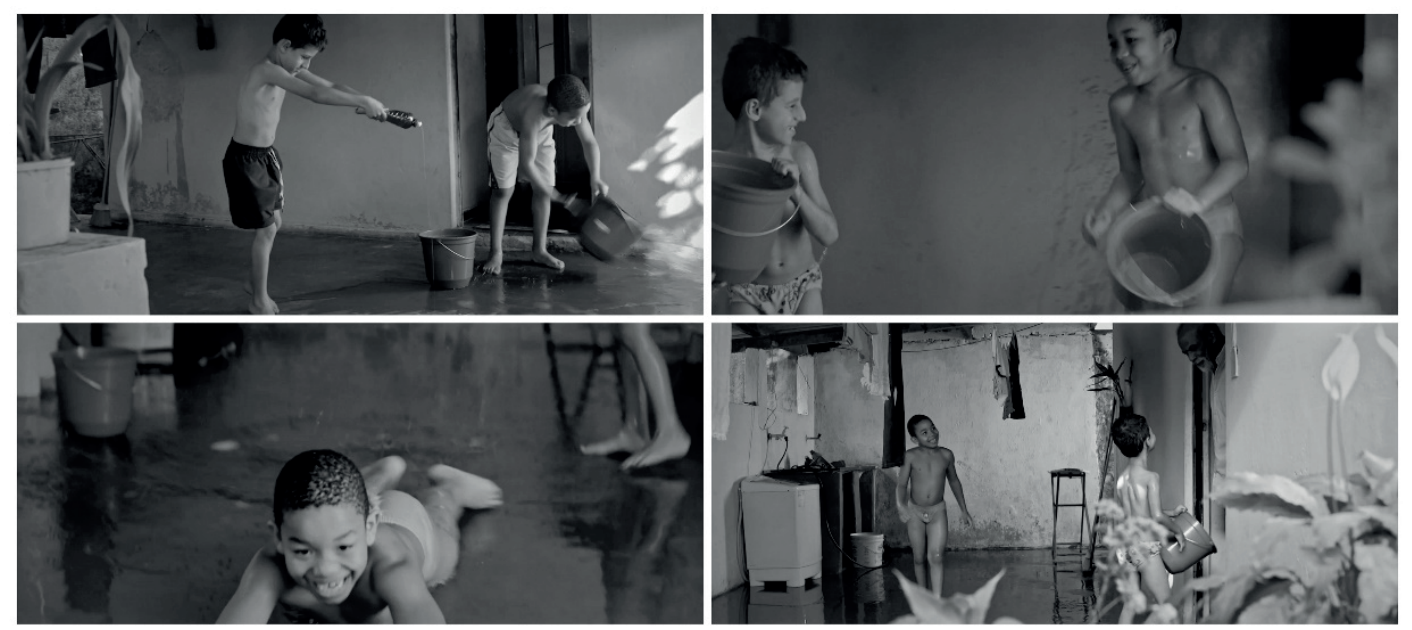

Fonte: Filme A Piscina de Caíque (Raphael Gustavo da Silva, 2017).

Os créditos iniciais do filme são reforçados com os ruídos sonoros de uma criança pulando em uma piscina, indicando também a água como um elemento que vai estar presente durante toda a narrativa do filme. Como é recorrente a falta de água na região e a família não tem caixa d’água, essa brincadeira de criança acaba se tornando um problema. Ao retornar do trabalho e ver que os recipientes de armazenamento de água estão vazios, a mãe de Caíque se enfurece e bate no menino. Ele vai buscar consolo junto ao avô, que promete darlhe uma piscina. Porém, após acalmar a situação e Caíque adormecer (Figura 6), o avô tem um ataque cardíaco e falece.

16 Antonio Pitanga é um dos mais importantes atores negros brasileiros. Iniciou sua carreira nos anos de 1960, atuando em filmes como Bahia de todos os santos (Trigueirinho Neto, 1960), O pagador de promessas (Anselmo Duarte, 1962), Barravento (Glauber Rocha, 1962), A grande feira (Roberto Pires, 1966). Dirigiu o longa Na boca do mundo, em 1978) e anos de 1980, atuou em Quilombo (Cacá Diegues,1984) e mais recentemente fez uma participação no filme Eu receberia as piores notícias dos seus lindos lábios (Beto Brant, 2011). Em 2016, foi lançado o documentário Pitanga, dirigido por Beto Brant e Camila Pitanga (filha do ator), que investiga seu o percurso estético, político e existencial. 
Figura 6 - Caíque adormece após ser consolado pelo avô

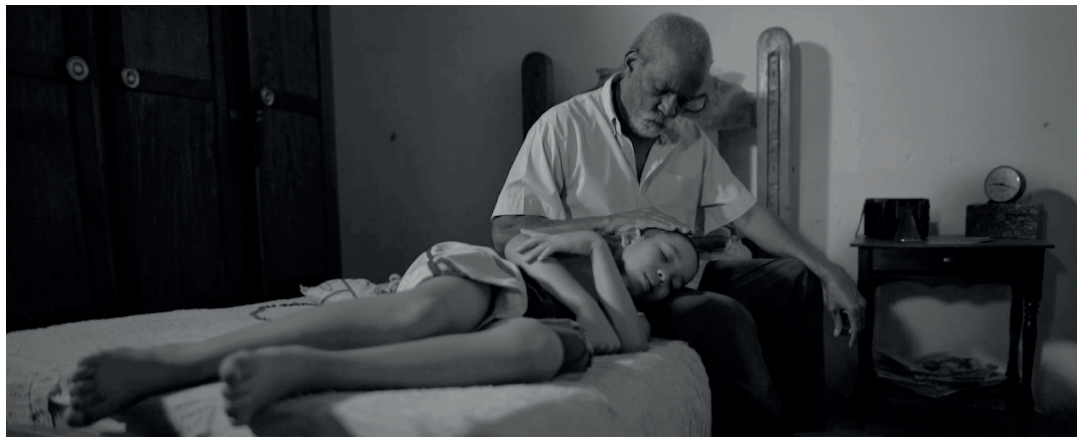

Fonte: Filme A Piscina de Caíque (Raphael Gustavo da Silva, 2017).

Na sequência seguinte, que agrega um avanço temporal na narrativa, o protagonista e seu amigo encontram o dinheiro deixado pelo avô e vão até uma loja de material de construção, onde imaginamos que eles vão comprar uma piscina inflável. A narrativa explora essa expectativa nessa cena e na seguinte, na qual os dois meninos conversam e o amigo questiona se eles fizeram a coisa certa, Caíque de maneira enfática responde: “Claro! Escorregar na área é muito melhor”. Os dois se abraçam e riem; em seguida, a câmera se desloca para mostrar que, em vez de uma piscina, Caíque comprou uma caixa d’água (Figura 7), algo que será útil para a sua família e garante a continuidade da brincadeira. Essa travessura que os dois amigos fazem com nossa expectativa é realçada novamente com a música; no plano final, sobrevoando o bairro, vemos o telhado das casas e a piscina de Caíque.

Figura 7 - A piscina de Caíque
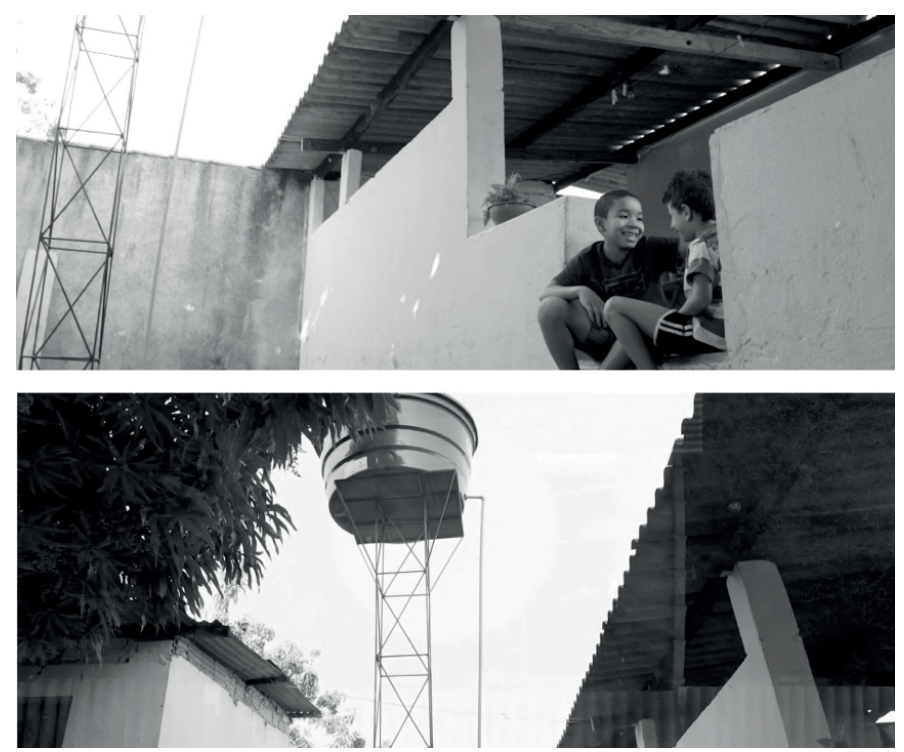

Fonte: Filme A Piscina de Caíque (Raphael Gustavo da Silva, 2017). 
Desde que foram lançados, A câmera de João e A Piscina de Caíque foram exibidos em vários festivais e mostras em diversos estados brasileiros; e também em escolas, o que permite uma aproximação entre o público infantil e tais representações audiovisuais. Nesse sentido, vale salientar que tais curtas apresentam crianças negras como protagonistas e, principalmente, em situações do cotidiano, como a prática da fotografia ou mesmo o exercício do brincar, oferecendo assim um contraponto às representações predominantes na TV e do cinema nacional, nas quais, conforme aponta Horta (2018), as crianças negras estão comumente limitadas a situações de racismo ou à pobreza e criminalidade.

\section{A mulher negra como protagonista no curta Viúva Negra}

O terceiro curta que integrou a mostra Filmes de Preto foi dirigido pela cineasta Vanessa Goveia, que também dividiu a autoria do roteiro com Gabriel Newton, outro egresso do curso de Cinema e Audiovisual da UEG. Viúva Negra ${ }^{17}$ é uma ficção que destaca a protagonista Olívia (interpretada pela atriz Débora Carolyne), uma mulher jovem, sensual e misteriosa, que faz jus ao título de "Viúva Negra”, usado no imaginário popular para designar mulheres que matam seus parceiros após a relação sexual, uma alusão às aranhas fêmeas do gênero Latrodectus também chamadas por esse termo, pois matam os machos da espécie após o acasalamento.

As cenas iniciais são de um jantar romântico de Olívia com Miguel (Adreane Lima), no qual, ela demonstra o sentimento especial que tem por ele, por isso demonstra hesitação, já que até então nunca havia se envolvido emocionalmente com suas vítimas. O corte para um conjunto de imagens que passam em ritmo acelerado e mostram Olívia se maquiando (em super close, que destaca seu rosto), fotos de homens com efeito de negativo que sugerem uma espécie de apagamento, objetos como uma câmera fotográfica, uma tesoura e uma cama constroem o pano de fundo para o título do filme e também dão indícios sobre a protagonista; a música reverbera essa atmosfera de mistério e suspense que a caracterizam.

$\mathrm{Na}$ primeira sequência, Olívia está caminhando e passa por um grupo quatro rapazes; ela sabe que está sendo olhada e um deles comenta "Essa daí tem cara de que engole tudo”. A câmera agora posicionada em posição frontal à personagem feminina, com os rapazes em segundo plano mostra que ela não se intimida e volta encarando o mais saidinho, interpela-o dizendo "quer conferir?” (Figura 8) e pede ao outro uma caneta, com a qual escreve seu número de telefone no pescoço do rapaz e enfatiza “Não vai perder, tá?”, deixando-o desconcertado. Os outros rapazes zombam dele e enquanto isso, Olivia continua tranquilamente sua caminhada.

17 Disponível no canal da Produtora Estratos Filmes: https://vimeo.com/204914408. Acesso em: 22 ago. 2020. 
Figura 8 - A postura audaciosa de Olívia
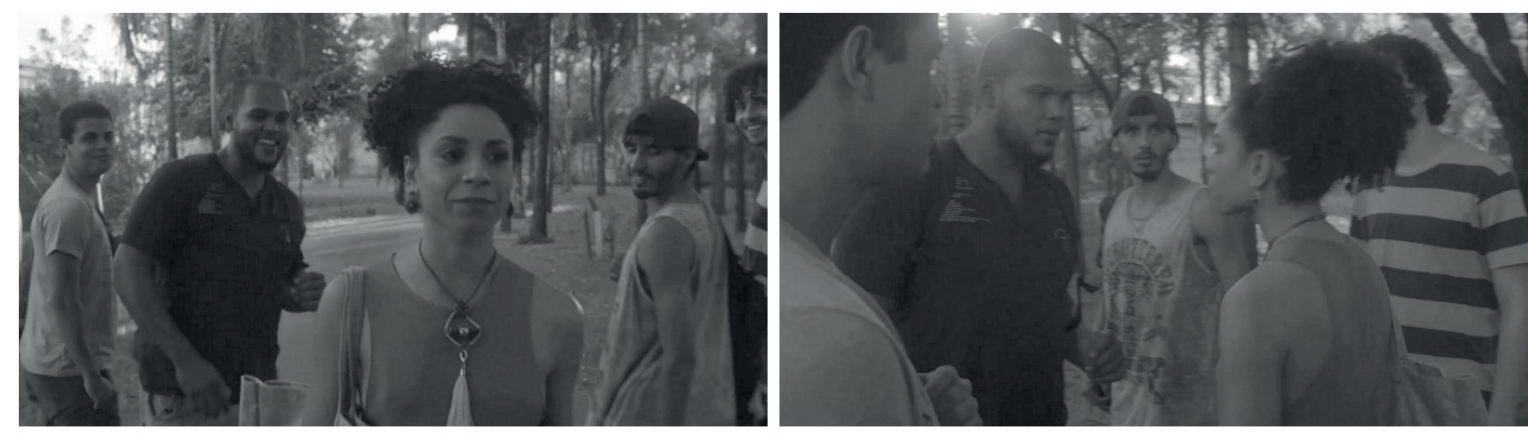

Fonte: Filme Viúva Negra (Vanessa Goveia, 2017).

Esse posicionamento da protagonista é reforçado nas estratégias de sedução que ela usa para conquistar diferentes homens. Ela não se importa quando um diz que é casado e não tem pudor quando tira a calcinha e dá de presente a outro, juntamente com seu número de telefone. Tais ações de ousadia intercalam a sequência do jantar, na qual ela novamente hesita, tenta resistir às investidas de Miguel, mas enfim se rende. A relação sexual evidencia o prazer dessa personagem feminina, que no dia seguinte tira uma foto de Miguel e coloca junto às demais no mural. Afirmando "eu não queria que você tivesse amanhecido aqui”, Olívia o mata com uma apunhalada nas costas e com uma expressão sádica, encara a câmera (Figura 9).

Figura 9 - Olívia mata Miguel e olha para a câmera
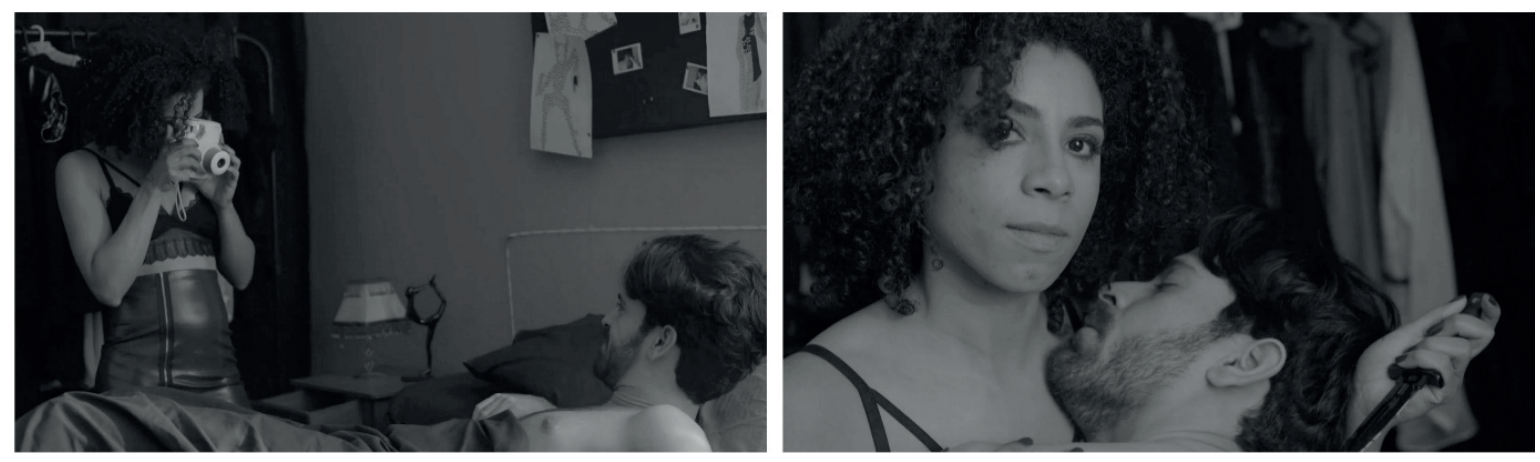

Fonte: Filme Viúva Negra (Vanessa Goveia, 2017).

Corta para os créditos, que novamente têm como pano de fundo a sensualidade de Olívia se maquiando, depois caminhando sozinha à noite (a música transmite a ideia de força e altivez); também são enquadradas as fotos de homens no mural e as pernas da protagonista em uma saia decotada). Tais imagens poderiam ser consideradas as cenas finais do curta, mas, após os créditos, há mais uma cena, por meio da qual a narrativa nos indica que a viúva negra continua sua saga, seduzindo e fotografando suas vítimas (Figura 10). Essa última imagem, com Olivia em destaque no centro do quadro e em uma posição de poder pelo 
domínio da sexualidade e principalmente, por que detém a câmera podem ser consideradas como uma metáfora do desejo da própria diretora em construir novas representações para mulheres negras no cinema.

Figura 10 - A saga de Olívia continua
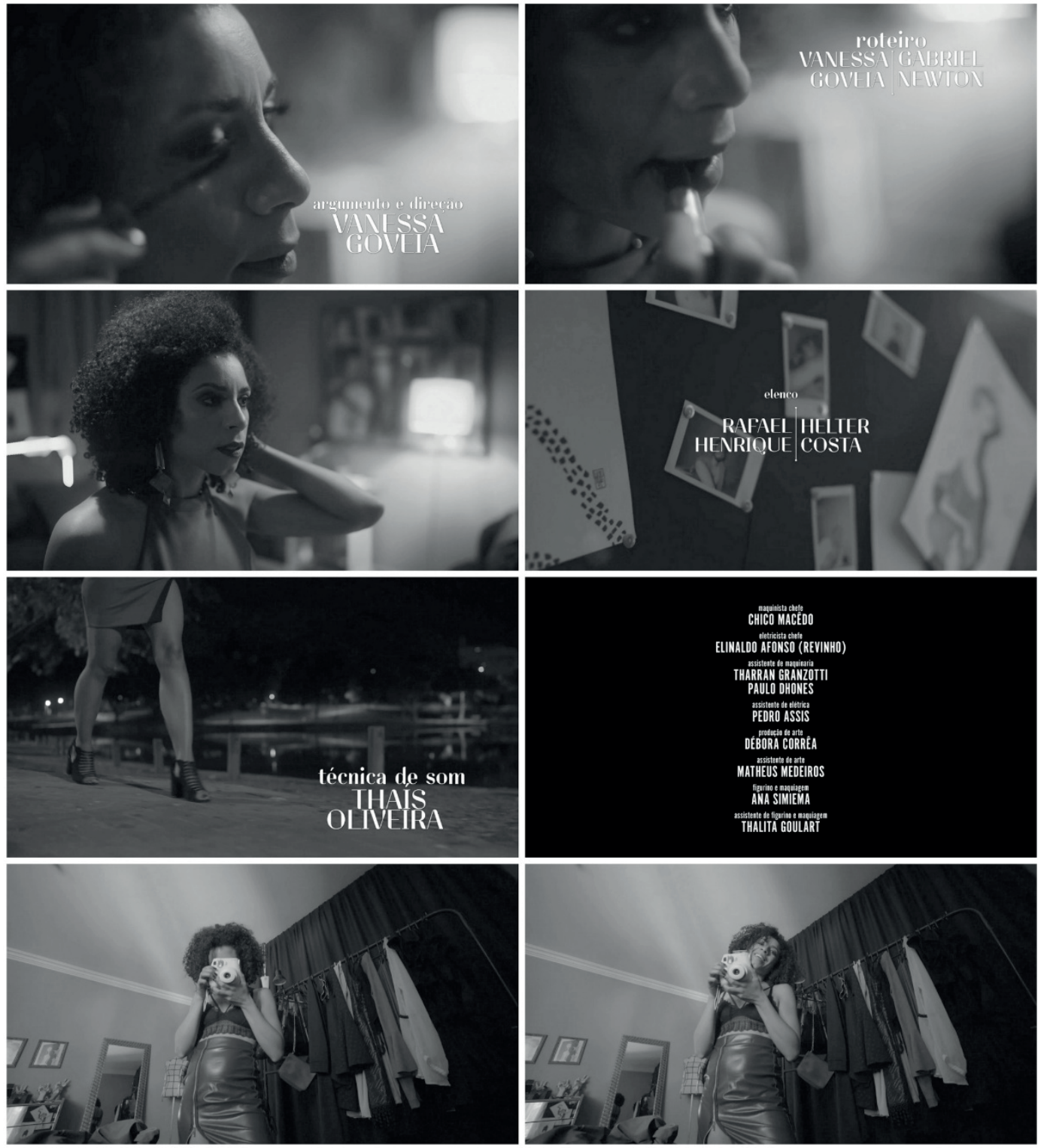

Fonte: Filme Viúva Negra (Vanessa Goveia, 2017).

O domínio que essa personagem feminina tem de si e de sua sexualidade é mostrado durante toda a narrativa e enfatizada quando Olívia mata Miguel e olha para a câmera, ação 
que confirma a autoconsciência dessa personagem, que quebra o distanciamento entre o filme e quem assiste, questionando assim a própria linguagem cinematográfica. Além disso, a construção dessa personagem feminina oferece elementos para pensar em um possível deslocamento nos territórios de gênero. Ela assume uma postura comumente associada ao masculino, visto que os homens usufruem de uma maior liberdade sexual e desde muito cedo a eles são permitidas aventuras sexuais dentro de um padrão heteronormativo (LOURO,1999), que também impõe de forma mais incisiva limites à sexualidade feminina, outrora somente no casamento e ainda hoje restrita a determinadas condutas.

A representação da sexualidade feminina no cinema também reproduz tais desigualdades. Nesse sentido, Kaplan (1995, p. 23) destaca como a figura da femme fatale nos filmes noir (dos anos de 1940) assume sua sexualidade e seduz os homens para atingir seus próprios interesses. Por isso, é vista como maligna, o que dá ao homem o direito moral de destruí-la, de puni-la com a morte e assim "o revólver ou a faca assumem o lugar do falo que deve, eliminando-a, dominá-la”. Em contraponto, essa teórica feminista aponta mudanças após os anos de 1960 e as profundas transformações culturais que ocorreram e possibilitaram a representação da mulher no exercício de sua sexualidade. Relacionando tais reflexões com o filme Viúva negra, especialmente a cenas finais (Figura 10), pode-se considerar que o desfecho dado à protagonista Olívia indica que ela resiste à dominação masculina, ao utilizar sua sexualidade como estratégia de sedução e também ao assumir o falo (nesse caso representado pela faca) para matar seus amantes, que são punidos por caírem na armadilha, enquanto ela continua em ação, andando sozinha à noite à procura da próxima vítima.

Nessa discussão sobre gênero e sexualidade, mostra-se fundamental chamar a atenção para o pertencimento racial. Pois, se a sexualidade feminina foi historicamente reprimida nas representações do cinema, isso se refere principalmente às mulheres brancas, que constituem modelos de feminilidade e beleza e assumem papeis centrais, enquanto as negras predominantemente são relegadas a personagens periféricos e sem densidade psicológica (YOUNG, 1996). Sobre o lugar de protagonismo de Olívia nesse curta, a diretora Vanessa Goveia pontua:

É uma produção que fala sobre o olhar feminino negro e, sobretudo, na forma de se colocar e expor as relações sociais e emocionais em relação a representatividade. O negro, quase sempre, é visto como o empregado, o garçom, o caricato, o personagem de humor ou o bandido. Sempre atrás do foco (FERREIRA, 2017b, s/p).

Em consonância com essa afirmação, Candido e Feres Júnior (2019) constatam a manutenção de um regime racializado e generificado de representação no cinema brasileiro no período de 2002 e 2014, indicado na recorrência de estereótipos como o da "empregada" e da "mulata”, que associam as mulheres negras à subserviência e a hipersexualização. A persistência de tais estereótipos nos remete aos estudos de Gonzalez (1984), que anos de 1970, 
já questionava como a naturalização dos papéis de "mulata” e doméstica era determinante para o reconhecimento social das mulheres negras.

Lélia Gonzalez traz a dimensão espacial das relações raciais, de gênero e sociais. Podemos apreender que a "mulata" seria no espaço público uma expressão correspondente à que é atribuída a doméstica no âmbito privado. [...] Ela reconhece aspectos remotos que são retomados e se atualizam para manter o corpo feminino negro como alvo de imagens públicas fixas, repetidas, quase sempre de inferiorização, negativas (RATTS; RIOS, 2016, p. 397).

Essa ênfase no olhar feminino negro, destacado pela jovem cineasta nos possibilita pensar o curta Viúva Negra como um contraponto ao tratamento subalterno que geralmente é dado às mulheres pretas e pardas nos filmes brasileiros de longa metragem lançados nos últimos vinte anos (1995 a 2014), nos quais “[...] apenas 1,4\% das atrizes não brancas são protagonistas” (CANDIDO et al., 2016, p. 15). Dessa forma, embora a sexualidade seja o elemento principal explorado nessa personagem, pois não sabemos nada mais sobre ela, o fato de ser a protagonista, de ser dona do seu desejo e do seu corpo complexifica esse lugar de mero objeto sexual, indicando fluxos, ambiguidades e polissemias capazes de romper a tendência de aprisionamento de personagens femininas negras (SOARES, 2009, SILVA, 2016). Logo, pode-se considerar que Vanessa, assim como outras cineastas tem empreendido um Cinema Negro no Feminino, que “[...] possibilita às diretoras negras recriar os espaçosterritório silenciados pelo racismo e pela heteronormatividade, [...] edificando assim formas plurais de abordar a diversidade. Por isso se constitui símbolo de empoderamento negro feminino (FERREIRA; SOUZA, 2017, p. 176).

Esse cruzamento de gênero e raça que estrutura a construção da personagem Olívia tem sido discutido em mostras e eventos nos quais o filme é exibido, como por exemplo na $1^{\text {a }}$ Mostra de Cinema Feministas de Quinta; e no debate do Cineclube Teresa de Benguela, ambos realizados em Vitória/ES, respectivamente em junho de 2017 e março de 2018; e nos possibilita ainda pensar o âmbito da produção audiovisual em Goiás, especialmente na função de direção. De acordo com um mapeamento de diretoras goianas no período de 2013 a 2018, do total de 22 mulheres, somente duas eram negras: Vanessa Goveia e Larissa Fernandes, constata Silva (2019).

Além da intersecção das assimetrias de gênero e raça, pode-se considerar ainda a exclusão regional como um fator que incide sobre a exclusão das mulheres na produção cinematográfica brasileira. Embora tal aspecto não tenha sido analisado no estudo "Diversidade de Gênero e Raça nos Longas-metragens Brasileiros Lançados em Salas de Exibição 2016” (BRASIL, 2018), observamos que, dos 142 longas que constituem o universo da pesquisa, 115 filmes foram produzidos por produtoras da Região Sudeste, apenas quatro são de produtoras da Região Centro-Oeste e não consta nenhum filme de produtoras da Região Norte. Isso confirma as desigualdades regionais e a necessidade de implementação 
de políticas públicas que incentivem a descentralização e a regionalização do audiovisual, possibilitando assim a emergência de novas vozes, paisagens, narrativas e representações.

\section{Considerações finais}

Os curtas A câmera de João e A Piscina de Caíque são protagonizados por crianças negras e centram-se no ambiente familiar e suas particularidades, como indícios da ausência do pai e a atuação da mãe como chefe de família. Porém, a alegria, a brincadeira e o ponto de vista infantil se destacam e, por meio dos quais, são também evidenciadas as relações de afeto que João e Caíque têm com seus avós idosos representados de forma diferenciada à situação de pobreza, abandono e subserviência que é recorrente nas representações da população negra em novelas e filmes nacionais.

Também nesse sentido, pode-se considerar que, se historicamente as mulheres negras são colocadas, em virtude de uma visão estereotipada sobre sua sexualidade, numa condição de objeto (no cotidiano e nas representações), é possível observar no curta Viúva Negra, com a protagonista Olívia, uma tentativa inversa, de lhe conferir protagonismo na construção narrativa e na imagem fílmica exatamente por ser dona do seu corpo e do seu desejo. Tais aspectos juntamente com a proposta da mostra/movimento cinematográfico Filmes de Preto são importantes para os processos de identificação e politização da imagem que essas produções podem suscitar em festivais e espaços de discussão, como mostras feministas, conforme mencionado.

Portanto, esses três jovens problematizam questões raciais, sociais e de gênero em suas narrativas audiovisuais; enfatizam a necessidade de ter realizadores/as e profissionais negros/as, porque compreendem a importância da criação de novas formas de visibilidade e assim exploram novos territórios simbólicos e imagéticos dos afetos, das brincadeiras de criança e do protagonismo feminino negro.

\section{Referências}

APROVADAS cotas para mulheres, negros e indígenas em edital para produção cinematográfica. Site da Agência Nacional do Cinema (ANCINE). Brasília, 28 de março de 2018. Disponível em: https:// www.ancine.gov.br/pt-br/sala-imprensa/noticias/aprovadas-cotas-para-mulheres-negros-e-ind-genasem-edital-para-produ-o. Acesso em: 14 abr. 2019.

ARAÚJO, J. Z. O negro na dramaturgia, um caso exemplar da decadência do mito da democracia racial brasileira. Estudos Feministas, v. 16, n. 3, p. 979, 2008.

AULA inaugural dá início ao Curso de Cinema e Audiovisual na UFMT. Site da UFMT, Cuiabá, 4 de maio de 2018. Disponível em: https://www1.ufmt.br/ufmt/site/noticia/visualizar/40439/Cuiaba. Acesso em: 20 ago. 2020.

AUSÊNCIA de negros em "Segundo Sol” motiva movimento com mais de 26 mil curtidas. Na telinha UOL. São Paulo, 29 abr. 2014. Disponível em: https://natelinha.uol.com.br/novelas/2018/04/29/ausencia-de-negrosem-segundo-sol-motiva-movimento-com-mais-de-26-mil-curtidas-116454.php. Acesso em: 25 ago. 2020. 
BATISTA, L. L.; LEITE, F. Diante das primeiras experiências de crianças negras brasileiras com o racismo: práticas parentais e narrativas midiáticas contraintuitivas. Novos Olhares, v. 6, n. 1, p. 20-36, 2017.

BRASIL, Agência Nacional do Cinema (ANCINE). Diversidade de Gênero e Raça nos Longasmetragens Brasileiros Lançados em Salas de Exibição 2016. Rio de Janeiro, RJ: Ancine - Agência Nacional do Cinema, 2018, 27 p. Disponível em: https://oca.ancine.gov.br/sites/default/files/repositorio/ pdf/informe_diversidade_2016.pdf. Acesso em: 2 jun. 2019.

CAIXETA. A. P. A.; OLIVEIRA, T. R. Construindo mundos com o som: uma análise da construção sonora no filme O menino e o mundo. In: XVII CONGRESSO DE CIÊNCIAS DA COMUNICAÇÃO NA REGiÃo CENTRO-OESTE, 2015, Campo Grande/MS. Anais.... Campo Grande: UFMS, 2015, p. 1-10. Disponível em: https://portalintercom.org.br/anais/centrooeste2015/resumos/R46-0540-1.pdf. Acesso em: 21 ago. 2020.

CAMPOS, L. A.; FERES JÚNIOR, J. Televisão em cores? Raça e sexo nas telenovelas “Globais” dos últimos 30 anos. Textos para discussão GEMAA, n. 10, 2015, p. 1-23. Disponível em: http://gemaa.iesp.uerj.br/wpcontent/uploads/2015/12/images_publicacoes_TpD_TpD10_Gemaa.pdf. Acesso em: 12 jan. 2019.

CANDIDO, M.; CAMPOS, L. A.; FERES JÚNIOR, J. A Cara do Cinema Nacional: gênero e raça nos filmes nacionais de maior público (1995-2014). Textos para discussão GEMAA, Rio de Janeiro, n. 13, p. 1-20, 2016. Disponível em: http://gemaa.iesp.uerj.br/textos-para-discussao/tpd13/. Acesso em: 7 abr. 2019.

CANDIDO, M. R.; MORATELLI, G.; DAFLON, V. T.; FERES JÚNIOR, J. A Cara Do Cinema Nacional: gênero e cor dos atores, diretores e roteiristas dos filmes brasileiros (2002-2012). Textos para discussão GEMAA, Rio de Janeiro, n. 6, p. 1-25, 2014. Disponível em: http://gemaa.iesp.uerj.br/wp-content/ uploads/2014/10/images_publicacoes_TpD_TpD6_Gemaa.pdf. Acesso em: 17 abr. 2019.

CANDIDO, M. R.; FERES JÚNIOR, J. Representação e estereótipos de mulheres negras no cinema brasileiro. Revista Estudos Feministas, v. 27, n. 2, 2019. Disponível em: https://www.scielo.br/pdf/ref/v27n2/18069584-ref-27-02-e54549.pdf. Acesso em: 17 jul. 2020.

CANDIDO, M. R.; TOSTE, V. O Brasil das telas de cinema é um país branco - A cara do cinema nacional 2002-2012 (Infográfico). Site do GEMAA, Rio de Janeiro, 2014. Disponível em: http://gemaa.iesp.uerj.br/ infografico/infografico1/. Acesso em: 20 ago. 2019.

CARVALHO, N. Esboço para uma História do Negro no Cinema Brasileiro. In: DE, J. Dogma Feijoada: O Cinema Negro Brasileiro. São Paulo: Imprensa Oficial do Estado de São Paulo: Cultura - Fundação Padre Anchieta, 2005. p. 17-101.

CASTRO, D. Após críticas, série sobre Marielle no Globoplay terá roteirista e diretor negros. Notícias da TV - Site UOL, 10 de março de 2020. Disponível em: https://noticiasdatv.uol.com.br/noticia/daniel-castro/aposcriticas-serie-sobre-marielle-no-globoplay-tera-roteirista-e-diretor-negros--34312. Acesso em: 25 ago. 2020.

CRENSHAW, K. Documento para o encontro de especialistas em aspectos da discriminação racial relativos ao gênero. Estudos Feministas, Florianópolis, v. 10, n. 1, p. 171-188, jan. 2002. Disponível em: https://www. scielo.br/pdf/ref/v10n1/11636.pdf. Acesso em: 24 ago. 2020.

CURTA Afirmativo: “o edital da autoestima”. Secretaria do Audiovisual, Ministério da Cultura, 20 de novembro de 2015. Disponível em: http://cultura.gov.br/curta-afirmativo-o-edital-da-autoestima/. Acesso em: 13 maio 2019.

FERREIRA, C. Cenário audiovisual goiano sob nova geração. Jornal O Popular. 24 de junho de 2017a. Disponível em: https://www.opopular.com.br/noticias/magazine/cen\%C3\%A1rio-audiovisual-goiano-sobnova-gera\%C3\%A7\%C3\%A3o-1.1298429. Acesso em: 10 maio 2019. 
FERREIRA, C. Movimento Filmes de Preto discute protagonismo negro no audiovisual. Jornal O Popular. 12 de agosto de 2017b. Disponível em: https://www.opopular.com.br/noticias/magazine/movimento-filmesde-preto-discute-protagonismo-negro-no-audiovisual-1.1326450. Acesso em: 14 maio 2019.

FERREIRA, C.; SOUZA, E. P. Formas de visibilidade e (re) existência no cinema de mulheres negras. In: HOLANDA, K.; TEDESCO, M. C. (orgs.). Feminino e plural: mulheres no cinema brasileiro. Campinas, SP: Papirus, 2017, p. 175-186.

GOIÁS Polo audiovisual - Levantamento da produção de cinema e Tv no Estado de Goiás 2017. Boletim Semanal da GoFilmes Goiânia, 17 fev. 2017.

GOMES, N. L. Cultura negra e educação. Revista Brasileira de Educação, Rio de Janeiro, v. 23, p. 1-11, maio/ago. 2003. Disponível em: https://www.scielo.br/pdf/rbedu/n23/n23a05.pdf. Acesso em: 21 ago. 2020.

GONZALEZ, L. Racismo e sexismo na cultura brasileira. Revista Ciências Sociais Hoje, São Paulo, p. 223244, 1984

GUIMARÃES, A. S. A. Raça, cor, cor da pele e etnia. Cadernos de Campo. São Paulo. v. 20, n. 20, p. 265271, 2011. Disponível em: http://www.revistas.usp.br/cadernosdecampo/article/view/36801/39523. Acesso em: 5 maio 2019.

HALL, S. Cultura e representação. Rio de Janeiro: Ed. PUC-Rio: Apicuri, 2016.

HORTA, A. Onde está a criança negra nas produções audiovisuais brasileiras?. Site Cinema Farol, 2018. Disponível em: https://cinemafarol.com/2018/11/12/onde-esta-a-crianca-negra-nas-producoes-audiovisuaisbrasileiras/. Acesso em: 17 mar. 2019.

KAPLAN, E. A. A mulher e o cinema: os dois lados da câmera. Tradução de Helen Marcia Potter Pessoa. Rio de Janeiro: Rocco, 1995.

LEITE, F. Por outras expressões do negro na mídia: a publicidade contraintuitiva como narrativa desestabilizadora dos estereótipos. In: BATISTA, L. L.; LEITE, F. (orgs.). O negro nos espaços publicitários brasileiros: perspectivas contemporâneas em diálogo. São Paulo: Escola de Comunicações e Artes/USP: Coordenadoria dos Assuntos da População Negra, 2011.

LOURO, G. Pedagogias da sexualidade. In: LOURO, G. (org.). O corpo educado: pedagogias da sexualidade. Belo Horizonte: Autêntica, 1999, p. 7-34.

MIGLIAVACCA, D. M. A imagem pelo buraco de uma agulha: uma experiência com fotografia artesanal. 2009. 67 f. Monografia (Bacharelado em Comunicação Social - Publicidade e Propaganda). Faculdade de Biblioteconomia e Comunicação - Universidade Federal do Rio Grande do Sul.

NOLETO, M. Produção de longas ganha fôlego em Goiás e projeta o Estado como polo de Produção. Jornal Opção. 17 março 2019. Disponível em: https://www.jornalopcao.com.br/opcao-cultural/producao-de-longasganha-folego-em-goias-e-projeta-o-estado-como-polo-de-producao-171410/. Acesso em: 14 ago. 2020.

O RENASCIMENTO do fazer cinema em Goiás. Revista de Cinema. 17 de fev. 2016. Disponível em: http:// revistadecinema.com.br/2016/02/o-renascimento-do-fazer-cinema-em-goias/. Acesso em: 20 mar. 2019.

PRADO, R. Produção e formação audiovisual “fora do eixo” no Brasil: o caso do Instituto Federal de Goiás. Revista Lusófona de Estudos Culturais, v. 6, n. 1, p. 249-262, 2019. Disponível em: https://revistas.uminho. pt/index.php/rlec/article/view/1865. Acesso em: 20 ago. 2020.

RAMOS, F. Estudos de Cinema na universidade brasileira. Alceu, Rio de Janeiro, v. 10, n. 20, p. 161-167, 2010. Disponível em: https://www.yumpu.com/pt/document/view/33997050/estudos-de-cinema-na-universidadebrasileira-alceu-puc-rio. Acesso em: 22 ago. 2020. 
RATTS, A. RIOS, F. A perspectiva interseccional de Lélia Gonzalez. In: MAGALHÃES PINTO, A. F.; CHAlHOUB, S. (orgs.). Pensadores negros - Pensadoras Negras: Brasil, séculos XIX e XX. Cruz das Almas: EDUFRB; Belo Horizonte: Fino Traço, 2013, p. 387-404.

RISTOW, F. Presidente da Ancine suspende repasse de verbas para o audiovisual. Jornal O Globo. Disponível em: https://oglobo.globo.com/cultura/filmes/presidente-da-ancine-suspende-repasse-de-verbaspara-audiovisual-23610669. Acesso em: 19 abr. 2019.

SILVA, C. F. Por trás das câmeras: diretoras no audiovisual goiano (2013-2018). Trabalho de Conclusão de Curso (Bacharelado em Cinema e Audiovisual) - Universidade Estadual de Goiás, Goiânia, 2019.

SILVA, C. M. F. Mulheres negras e (in)visibilidade: imaginários sobre a intersecção de raça e gênero no cinema brasileiro (1999-2009). 2016. 297 f. Tese (Doutorado em Comunicação) - Faculdade de Comunicação, Universidade de Brasília, Brasília, DF, 2016.

SILVA, L. R. O cinema digital e seus impactos na formação em cinema e audiovisual. 2012, $280 \mathrm{f}$. Tese (Doutorado em Comunicação) - Escola de Comunicações e Artes, Universidade de São Paulo. São Paulo, SP, 2012.

SHOHAT, E.; STAM, R. Estereótipo, realismo e luta por representação. In: SHOHAT, E.; STAM, R. Crítica da imagem eurocêntrica: multiculturalismo e representação. Trad. Marcos Soares. São Paulo: Cosacnaify, p. 261-312, 2006.

SOARES, D. M. O. Refletindo sobre a representação de mulheres negras brasileiras a partir de fragmentos das trajetórias de três atrizes pioneiras: Ruth de Souza, Léa Garcia, Taís Araújo. In: REUNIÓN DE ANTROPOLOGíA DEL MERCOSUl (RAM), 8, 2009, Buenos Aires. Anais.... Buenos Aires, 2009. p. 1-15. v. 1.

TONHATI, W. UFMS aprova criação do curso de bacharelado em Audiovisual com 30 vagas. Jornal Midia Max, 16 ago. 2018. Disponível em: https://www.midiamax.com.br/cotidiano/2018/ufms-aprova-criacao-docurso-de-bacharelado-em-audiovisual-com-30-vagas. Acesso em: 20 ago. 2020.

VANOYE, F.; GOLIOT-LÉTÉ, A. Ensaio sobre a análise fílmica. Tradução de Marina Appenzeller. Campinas, SP: Papirus, 1994.

VELASCO, S. Sob a luz tropical: racismo e padrões de e cor da indústria fotográfica no Brasil. Revista Zum. 13 de junho de 2016. Disponível em: https://revistazum.com.br/revista-zum-10/racismo-padroes-industriabrasil/. Acesso em: 17 jun. 2019.

YOUNG, L. The rough side of the mountain: black women and representation in film. In: JARRETTMACAULEY, D. (Ed.). Reconstructing womanhood, reconstructing feminism: writings on black women. London: Routledge, 1996. p. 177-202.

\section{Ceiça Ferreira}

Doutora em Comunicação pela Universidade de Brasília (UnB). Professora e pesquisadora do curso de Cinema e Audiovisual da Universidade Estadual de Goiás (UEG), onde desenvolve atividades de ensino, pesquisa e extensão nas áreas de comunicação e cultura, cinema, raça e gênero. E-mail: ceicaferreira@gmail.com. 
NOVAS FORMAS DE VISIBILIDADE: REPRESENTAÇÕES DE GÊNERO E RAÇA NO AUDIOVISUAL EM GOIÁS

\section{Clarissa Carvalho}

Graduada em Cinema e Audiovisual pela Universidade Estadual de Goiás (UEG). E-mail: clarissacrvlh@gmail.com.

Recebido em: 07.07.2019

Aprovado em: 18.09.2020 